Bulletin of the Natural History Museum, 2018, 11: 189-210.

Received 04 Sep 2018; Accepted 20 Nov 2018.

doi: $10.5937 /$ bnhmb $1811189 \mathrm{~N}$

UDC: $582.711 .714(497.11)$

Original scientific paper

\title{
A NEW SPONTANEOUS HYBRID BETWEEN THE CULTIVATED AND WILD IRIS SPECIES FROM SERBIA
}

\author{
MARJAN NIKETIĆ ${ }^{*}$, GORDANA TOMOVIĆ2 ${ }^{2}$ SONJA SILJAK-YAKOVLEV ${ }^{3}$ \\ ${ }^{1}$ Natural History Museum, 11000 Belgrade, Serbia, e-mail: mniketic@nhmbeo.rs \\ ${ }^{2}$ Institute of Botany and Botanical Garden, Faculty of Biology, University of \\ Belgrade, 11000 Belgrade, Serbia, e-mail: gtomovic@bio.bg.ac.rs \\ ${ }^{3}$ Ecologie Systématique Evolution, Univ. Paris-Sud, CNRS, AgroParisTech, \\ Université Paris-Saclay, 91400 Orsay, France, e-mail: sonia.yakovlev@u-psud.fr
}

A new spontaneous wilding hybrid, Iris $\times$ seminaturalis Niketić, Tomović \& Šiljak-Yak. (I. × germanica L. s.1. $\times$ I. reichenbachii Heuff.) from C Serbia was described and illustrated. The comparative analyses of the morphological characters and genome sizes were performed on $I$. $\times$ seminaturalis and its parents. A new taxonomic review of the complex $I$. × germanica s.l. was also presented.

Key words: vascular flora, Iris $\times$ seminaturalis, Iris $\times$ germanica, spontaneous hybrid, Serbia

\section{INTRODUCTION}

With six subgenera, 301 currently accepted species, 17 hybrids and 27 additional non-type subspecies (Barker \& Govaerts 2018), genus Iris L. has 
the richest taxonomic diversity in the family Iridaceae (Asparagales). Five subgenera are widespread in the Palaearctic, while subgenus Limniris (Tausch) Spach is distributed in the Holarctic. Most of the European species belong to the type subgenus with rhizomatous stocks and equitant ensiform leaves (Webb \& Chater 1980). Representatives of the type section, I. sect. Iris (Pogoniris), are the most numerous among them. In the horticultural classification, they are included among the Bearded Irises (B), also comprising some related sections (Warburton \& Gantz 1970).

Four native species from $I$. sect. Iris are presented in the Flora of SR Serbia: I. pumila L. $(2 \mathrm{n}=32)$, I. suaveolens Boiss. \& Reut. $(2 \mathrm{n}=24), I$. variegata $\mathrm{L} .(2 \mathrm{n}=24)$ and $I$. reichenbachii Heuff. $(2 \mathrm{n}=24)$ (StjepanovićVeseličić 1976). The lattermost species is widespread in a hilly-mountainous area and gorges of the Balkan Peninsula and SW Romania. It is 5$30(35) \mathrm{cm}$ tall perennial, with keeled bracts, 1-2 usually yellowish (rarely violet to brownish-purple) flowers, and with hypanthial tube, much shorter than the perianth segments. According to horticultural classification, it belongs to the MDB class (Miniature Dwarf Bearded Irises) (Warburton \& Gantz 1970). This plant inhabits dry pastures and rocky places, on different geological substrata, up to subalpine zone (Stjepanović-Veseličić 1976). The taxonomic status of a similar plant, I. bosniaca Beck, with broader falcate leaves, inflated bracts and longer filaments, is still doubtful and this name is currently not accepted (Barker \& Govaerts 2018). However, from the karyological point of view, there are significant differences between these two plants (Siljak-Yakovlev et al. 2005). Hybridogenous potential of I. reichenbachii is confirmed by the existence of $I$. $\times$ kobasensis Prodan ( $I$. reichenbachii $\times I$. variegata). According to Barker \& Govaerts (2018), this is the only currently accepted natural Balkan hybrid, described and known from Bosnia and Herzegovina. However, I. reichenbachii is also a putative progenitor of hybridogenous $I$. orjenii Bräuchler \& Cikovac from $\mathrm{SW}$ Montenegro (Bräuchler \& Cikovac 2007).

In 2002, during the field excursion to the southern part of C Serbia, two unusual iris clusters were observed in a forest clearing within yellowishflowering population of $I$. reichenbachii (Fig. 1). They were significantly higher, with more numerous and larger flowers, and with pale bluish falls and dark violet veins. Although it could be assumed that the plants were of hybrid origin, the second ancestral species was not observed in the habitat. By all accounts, this progenitor should have a violet to bluish flowers. However, in the Serbian flora there is no such native plant from I. sect. Iris. Fortunately, many ramet clusters of cultivated $I$. × germanica L. s.l. were found at a nearby cemetery (Fig. 2). So, the origin of the new putative hybrid plant was initially presumed basis on intermediary morphological traits and adjacent habitats of I. reichenbachii and I. × germanica s.l. 


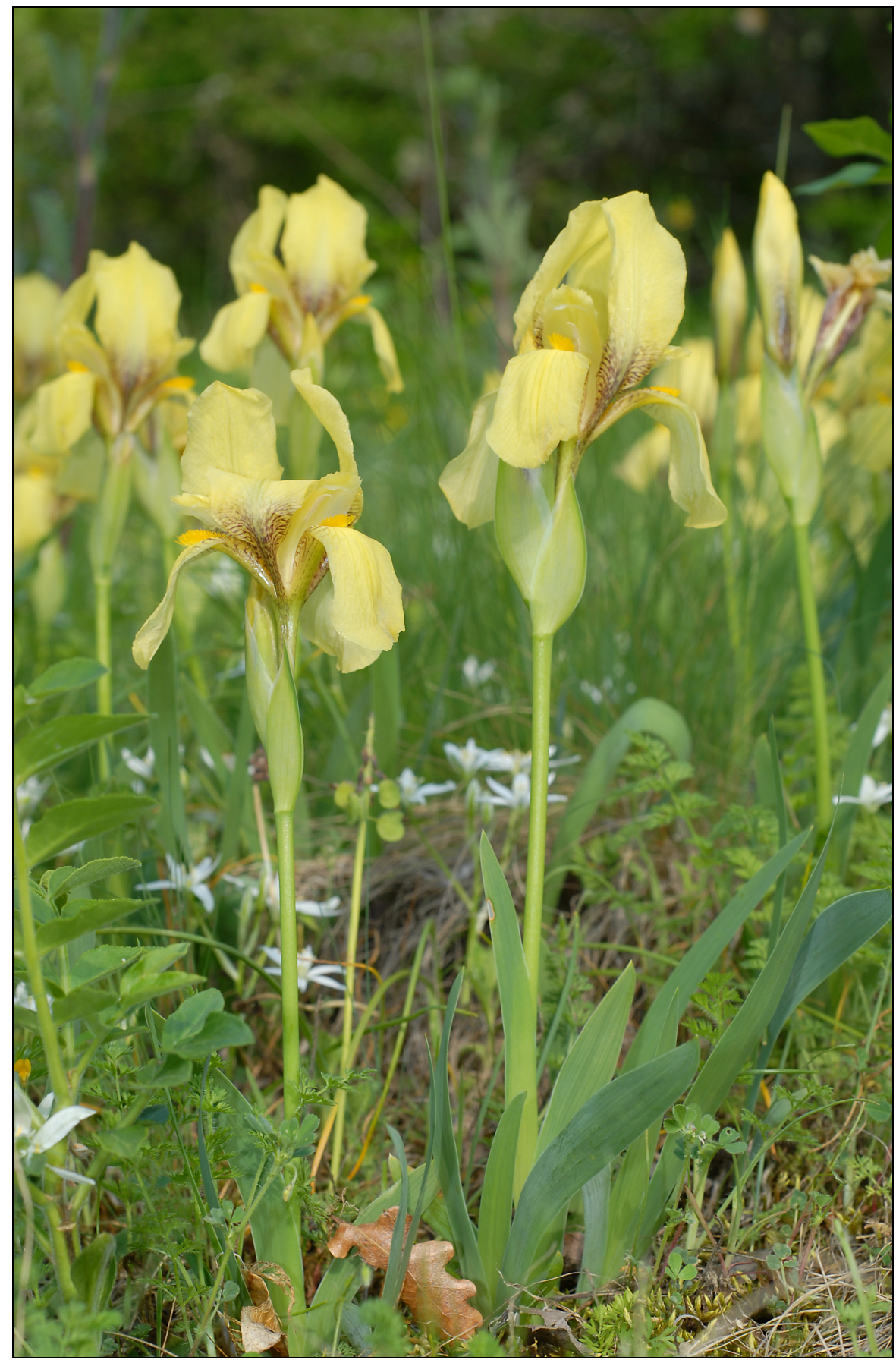

Fig. 1. - Parental species Iris reichenbachii Heuff. on natural habitat in $\mathrm{C}$ Serbia near Prokuplje (photo M. Niketić). 
192 NIKETIĆ, M. ET AL.: A NEW SPONTANEOUS IRIS HYBRID FROM SERBIA

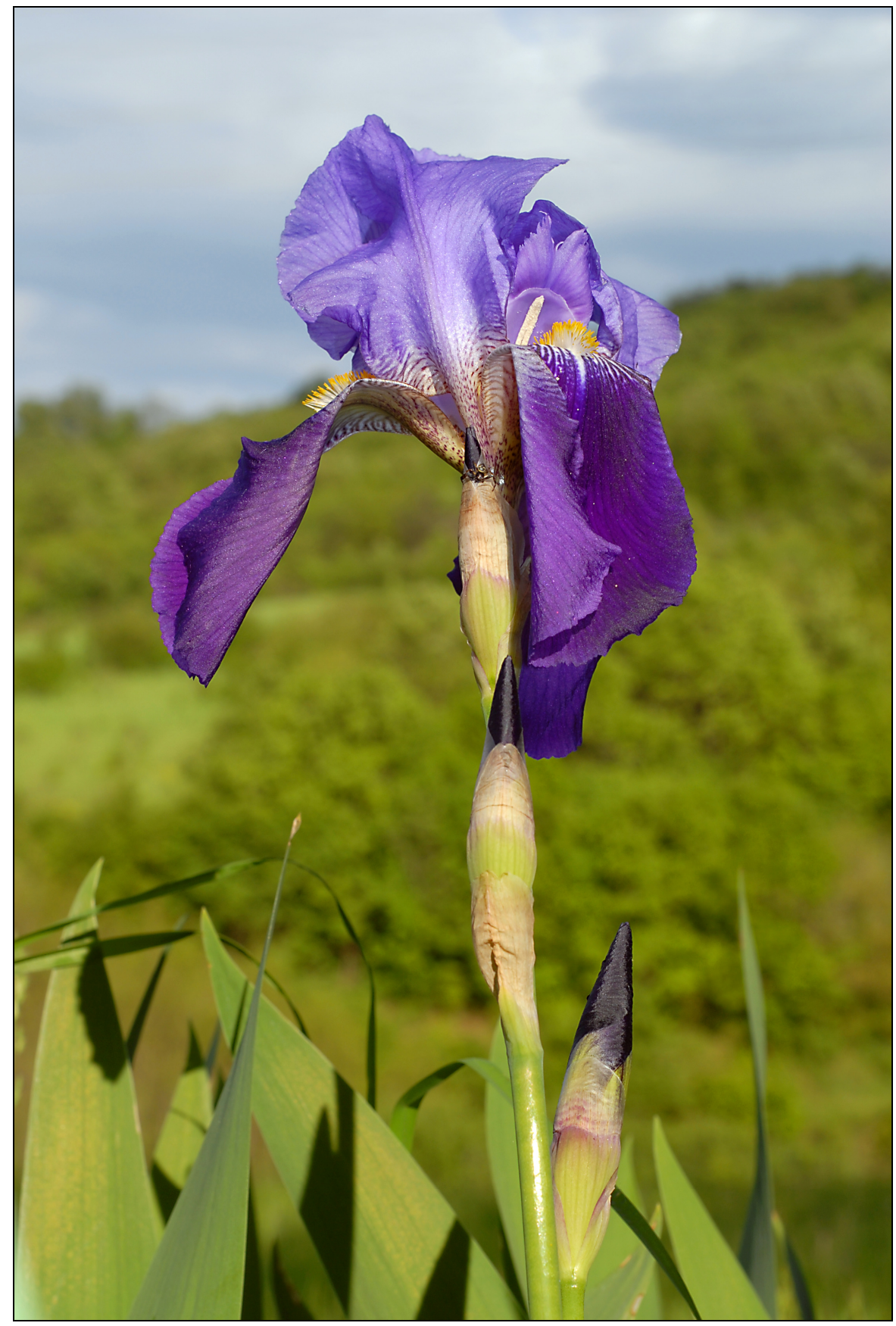

Fig. 2. - Parental plant Iris $\times$ germanica L. s.1. (I. $\times$ trojanensis group) on the cemetery near the natural habitat of $I$. reichenbachii in C Serbia near Prokuplje (photo M. Niketić). 


\section{Understanding the name of Iris $\times$ germanica}

Although the origin of $I$. xgermanica is uncertain, many authors consider it a synanthropic natural hybrid complex of Intermediate and Standard Tall Bearded Irises (IB, STB) from I. sect. Iris. It had been known in horticulture from ancient times as ornamental, aromatic and medicine plant, while it was introduced in plant science during the Renaissance era when Clusius described 28 varieties of 11 bearded irises (Wister 1978, Gessert 2010). It grows spontaneously in dry and stony soils, along the roads, borders, on cemeteries, in vineyards and former areas of cultivation, in the terraced fields, on beaches and in old abandoned house yards. It has been usually reported as ferals on the slopes near settlements, fortresses and ruins. According to Mathew (1981) it is a doubtful wilding, "propagated vegetatively and distributed locally giving the impression of having stable populations with a distinct geographical range" and appears never to occur in truly wild situations (Mathew 1984, 1991).

The plant was initially distributed in C and S Europe, the Mediterranean, and $\mathrm{W}$ Asia. It belongs to rhizomatous clonal perennial hybrids and in the flora of the British Isles more than $2 / 3$ of such hybrids are infertile or slightly fertile (Preston \& Pearman 2015). However, thanks to vegetative propagation that hybrids commonly occurred in areas without one or both parents ( $20 \%$ vs. $1 \%$ of nonclonal hybrids) [calculated here from (Preston \& Pearman 2015)]. Thus, the range of $I$. × germanica s.l. occupies a much larger area of potential places of origin (C Apennine and W Balkan Peninsulas). According to Prodan (1939), among the 1000 specimens of German Iris it is difficult to find one with fruit; even when found, they tend to have very few seeds. Furthermore, seedlings are difficult to obtain and are usually dwarfed (Dykes 1924), while malformations of the flowers are frequent (Dykes 1914). However, it is noticeable that in typical bluish flowered IB/STB forms fertility rises from west to east, and several \pm fertile tetraploid clones $(2 n=48)$ have been found in SW Asia, causing many authors to consider them independent species.

Mathew $(1981,1984,1991)$ was the first who lumped almost all IB and STB hybrid irises in I. × germanica as "one of the number of hybrids of unknown and fairly ancient origin". His treatment is mainly accepted in some of the most prominent current floras and checklists, including a few dozen of described taxa, with the exception of the I. ×florentina group and modern cultivars (Henderson 2002, Barker \& Govaerts 2018). According to them, all lineages arose through the hybridisation of blue Dalmatian and yellow Hungarian Irises, I. pallida L. and I. variegata. Subsequent backcrossing led to the appearance of different genetic and phenetic patterns, varying from one parental extreme to the other. However, 
considering the karyological data and the results of experimental crossings, the possible origin of these strains seems to be much more complex.

For this complex, two main ancestral base numbers were reported. The first $(\mathrm{x}=11)$ includes allotetraploid hybrids $(2 \mathrm{n}=44)$, which are usually reported in specimens having characteristics that are similar to those of Linnaean $I$. $\times$ germanica. The second $(\mathrm{x}=12)$ includes diploids $(2 \mathrm{n}=24)$ and polyploids $(2 \mathrm{n}=36,48,60)$. A new base number $(\mathrm{x}=10,2 \mathrm{n}=40)$ was also recently reported from China (Yu et al. 2007), but this record requires verification. Based on the chromosome number and morphology, included plants can be separated into several groups of possible different origins. In any case, the hypothesis of I. aphylla L. as a possible ancestor (other parent is unknown) (Dykes 1924) was not confirmed experimentally and should be rejected.

\section{I. $\times$ SAMBUCINA GROUP (I. pallida s.1. $\times$ I. variegata)}

Diploids $(2 \mathrm{n}=24)$

IB to STB (infertile to fertile)

At the beginning of the $19^{\text {th }}$ century, Paul de Bure showed in breeding experiments that several old STB irises actually represent hybrids of $I$. pallida and I. variegata (Mahan 2007). Compared to the type I. ×germani$\mathrm{ca}$, these hybrids often have yellower flowers, and their falls are more elongated with conspicuous deep violet to brownish-red veins on the entire surface. Conflict between blue and yellow colour often produces muddy or squalid shades (Dykes 1914). There are several old hybrid variants with various ratios of yellow and blue (I. × sambucina L., I. $\times$ squalens L., $I$. $\times$ lurida Aiton, I. $\times$ neglecta Hornem., I. $\times$ amoena Hornem.), some of which some have been recognised as independent infertile or fertile hybrids (Colasante \& Maury 2018).

According to Dykes (1914) almost innumerable variants between $I$. variegata and I. pallida have been observed. The area of the potential origin of these hybrids are limited to the Dinaric Alps in W Balkans and only one locality of the natural hybrid has been known to date. The plant was found by Degen on Mts. Velebit in 1912 (in the vicinity of Karlobag in NW Croatia). It was inspected by Dykes in 1913 (Dykes 1914a), and twenty two years later it was formally named and published as $I$. $\times$ rotschildii Degen "(illyrica $\times$ variegata $)$ " (Degen 1936). Twelve years ago, the same hybrid was rediscovered in the vicinity of Karlobag (Mitic et al. 2006) and karyologically investigated (Siljak-Yakovlev et al. 2008). This homoploid hybrid $(2 \mathrm{n}=24)$ includes an entire series of backcrossed morphologically intermediate individuals (a hybrid swarm), varying in combinations of yellow and blue colour. The investigated individuals, morphology pretty much corresponded to some of the mentioned cultivars (Warburton \& Gantz 1970). The same situation had been also observed by 
Dykes (1914a) on locus classicus. Concerning pollen morphology, I. $\times$ rotschildii has a small amount of fertile pollen grains, similar to $I$.

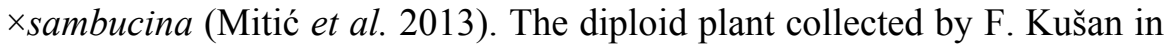
Mt. Dinara massif in Dalmatia, southeast of Mt. Velebit and identified as $I$. $\times$ squalens (Warburton \& Gantz 1970) can be a similar or same natural hybrid.

I. $\times$ TROJANA GROUP (uncertain origin)

Allo- or autotetraploids $(2 n=48)$, sometimes diploids $(2 n=24)$

STB (fertile to slightly fertile)

This is a very heterogeneous group, distributed mainly in the Orient, Levant and the Balkan Peninsula. Limb of the falls is bluish-violet, with a whitish to yellowish zone and a conspicuous violet venation limited to the lower $1 / 3$ of the limb or slightly more. It comprises different old lineages that are poorly investigated and morphologically hardly distinguishable: $I$. $\times$ trojana A. Kern. ex Stapf (NW Anatolia) (the oldest name), I. × cypriana Foster \& Baker (Cyprus), I. × germanica nothovar. askabadensis Dykes (Turkmenia), I. × germanica nothovar. amas Dykes (Anatolia: Amasia), I. $\times$ belouinii Bois \& Cornuault (Morocco and Algeria), I. ×cypriana Foster \& Baker (Cyprus, Anatolia), I. ×mesopotamica Dykes (Orient, Syria, Israel). According to many authors, I. $\times$ trojana and the last two above listed irises could be recognised as independent allotetraploid native species (Dykes 1924, Henderson 2002, Samad et al. 2016, Colasante \& Maury 2018), and at the end of the $19^{\text {th }}$ century they were used in the process of production of new cultivars by forced hybridisations with the original clones of $I$. $\times$ germanica s.s. In comparison with them, representatives of this group are taller and larger, later flowering plants (June vs. May), with usually more scarious bracts (but almost herbaceous in some clones), an often larger yellowish zone on the limb of the falls, and usually bicolorous flowers. Similar STB tetraploid fertile irises, I. ×altobarbata A. E. Murray (Murray 1969), correspond to modern cultivars only (usually with strongly undulate falls) and should be excluded from this group.

It is interesting to note that the presence of this group in $\mathrm{S}, \mathrm{C}$ and $\mathrm{E}$ parts of the Balkan Peninsula and Romania (Warburton \& Gantz 1970, Aldén 1976, Blažek 2016) has been usually neglected. It is either native or was introduced from the East during the rule of the Ottoman Empire. With the exception of $I$. × varbossiana $\mathrm{K}$. Malý from Bosnia and Herzegovina and probably I. hellenica Mermygkas, Kit Tan \& Yannits. from the Peloponnese in Greece, they are still unidentified and unnamed. Some of them were also observed as fertile plants in the wild (Warburton \& Gantz 1970, Mermygkas et al. 2010).

Two ploidy levels were recorded for synanthropic I. ×varbossiana, with diploids (Simonet 1952) and tetraploids (Randolph \& Mitra 1959). 
According to Samad et al. (2016), tetraploid plants reported by SiljakYakovlev et al. (2005) for "I. × germanica" from Bosnia and Herzegovina (probably corresponding to $I$. ×varbossiana) could be an autopolyploids. $I$. mesopotamica, on the other hand, could be an interspecific hybrid, and ribosomal RNA genes mapping enables the distinction between plants from the Balkans and I. mesopotamica (Abdel Samad et al. 2016). Diploids are also reported from Bulgaria (Popova \& Česchmedjiev 1975, sub I. $\times$ germanica). As there are no data on their fertility, and other features, finding and studying the diploid populations would bring us closer to resolving the origin of this group.

Although it is generally accepted that representatives of the $I$. $\times$ trojana group possess a high rate of fertility, this has never been inspected in situ. It is known that $I$. x germanica nothovar. amas produces only fertile pollen (Anonymous 1923) and, according to Mathew, various irises described as species in Turkey actually represent "sterile or near sterile clones which are propagated vegetatively".

I. CROATICA

Autotetraploids? $(2 \mathrm{n}=48)$

STB (fertile)

Particular tetraploid, I. croatica Horvat \& M. D. Horvat, is known as native fertile species in the area near the NW boundaries of distribution of I. ×trojana group, in the Peripannonian parts of NW Croatia and E Slovenia. The plant grows on clearings and margins in thermophilous pubescent oak forests. It has inflated herbaceous to slightly scarious bracts, very small bright basal area on the limb of the falls, and a karyotype that is similar to that of $I$. ×xypriana and I. kashmiriana Baker (Warburton \& Gantz 1970). The plant was initially connected with I. aphylla (Horvat \& Horvat 1962) and later was synonymised with I. × germanica (Barker \& Govaerts 2018), but Mitić et al. (2013) presumed that I. croatica could be an autotetraploid of I. pallida s.l. In our opinion, this tetraploid probably arose as a result of polyploidisation of backcrossed hybrid progenies between I. pallida $\times$ I. variegata (I. $\times$ rotschildii), more similar to I. pallida. Since this single clone (Warburton \& Gantz 1970) was discovered relatively late (Horvat \& Horvat 1962), it may correspond to some artificial tetraploid cultivar from the $I$. ×altobarbata group that has escaped from cultivation, but this is less likely. It is expected that future molecular and karyological research will clarify the origin of this plant.

According to Barker \& Govaerts (2018) the name I. croatica Horvat \& M. D. Horvat is illegitime as a younger homonym of I. croatica Prodan (1931). However, on the cited page (15) Prodan (1931) actually published I. $\times$ cavarnae Prodan (from I. ×trojana group), not $I$. croatica. The epithet croatica does not appear anywhere in Prodan's publication. 
I. $\times$ GERMANICA GROUP (I. lutescens s.1. $\times$ I. $\times$ trojana s.1. or I. croatica)

Allotetraploids $(2 \mathrm{n}=20+24=44)$

IB (infertile to slightly fertile)

Karyotype and chemotaxonomic analyses and experimental crosses indicated that 44-chromosome hybrids originated from tetraploid representatives of Standard Dwarf Bearded Irises (SDB) $(2 \mathrm{n}=40)$ and STB $(2 \mathrm{n}=$ 48) (Mitra 1956, Werckmeister 1981, Williams et al. 2000, Colasante \& Maury 2018). The first progenitors represent allotetraploid hybridogenous species distributed in the W Mediterranean. I. lutescens Lam., with pale yellow to violet flowers is most widespread. The few remaining species are endemic to Italy (Colasante \& Maury 2018). Second progenitors from the $I$. $\times$ trojana complex have E Mediterranean distribution. The occurrence of STB "I. croatica" $(2 \mathrm{n}=48)$ in NW Croatia and E Slovenia, not so far from that of tetraploid SDBs, led some authors to the conclusion that their natural hybrids arose in their former contact zone (Mitra 1956).

The original hybrid forms of $I$. × germanica were of lower (intermediate) growth and subsequently have been selected for higher growth (Henderson 2002). In comparison with those from the I. ×trojana complex, the representatives of $I$. × germanica group have slightly lower growth, less scarious bracts, usually concolorous flowers, an often smaller whitish zone on limb of the falls, and they rarely produce fruits and seeds. However, the emergence of new artificial hybrids has blurred the identification of these differences.

Although almost infertile, I. ×germanica is also considered the nomenclatural type of the genus. Its lectotype was designated from cultivated material from the garden of George Clifford III in Holland (Mathew ex Jarvis et al. 1993). Taking into account slight differences between $I$. × germanica and I. ×trojana group, the suggested chromosome number of the original Linnaean plant $(2 n=44)$ requires confirmation.

This group also comprises two pale white flowered cultivars $(I . \times$ florentina L. and $I$. $\times$ albicans Lange), Iris $\times$ biliottii Foster (Anatolian Black Sea region), as well as $I$. $\times$ germanica nothovar. fontarabie Dukes (Iberian Peninsula) and I. $\times$ kochii A. Kern. ex Stapf (NW part of the Balkan Peninsula).

MODERN CULTIVARS (complex origin)

$(2 \mathrm{n}=32,44,48)$

IB, STB (infertile to slightly fertile)

At the end of the $19^{\text {th }}$ century, Sir Michael Foster started the process of target crossing of I. × germanica (old clones) with tetraploid lineages of $\mathrm{E}$ Mediterranean I. ×trojana group, producing larger and more resistant 
cultivars. Murray (1969) named all artificial tetraploid cultivars I. ×altobarbata.

In the $20^{\text {th }}$ century many other species from Europe and Asia were included into the breeding: I. lutescens Lam., I. pontica Zapal., I. reichenbachii, I. imbricata Lindl., I. pumila, I. aphylla, etc. For artificially created hybrids, Henderson $(1993,2002)$ proposed a new group name, $I$. $\times$ conglomerata N. C. Hend., which should be distinguished from the complex I. × germanica s.l. The emergence of thousands of new artificial hybrids led to a significant reduction of ancient cultivars, which remained mainly in rural gardens and habitats.

KEY FOR I. PALLIDA AND OLD HYBRID GROUPS OF I. $\times$ GERMANICA S.L.

1a Limb of the fall with dark veins on the brighter background on the entire or nearly entire upper surface (similar to I. variegata) [Limb of the fall obovate to obovate-spathulate. Limb of the standard strongly undulate. Unfertile to slightly fertile plants. $2 n=24]$. I. sambucina aggr.

$1 \mathrm{~b}$ Limb of the fall with brighter background limited to the basal part of the upper surface or absent. . . . . . . . . . . . . . 2

2a Bracts and bracteoles completely scarious at anthesis. Limb of the fall have no dark veins on a brighter background on the upper surface, rarely at the base. Limb of the standard strongly to moderately undulate. $2 n=24$ [Limb of the fall obovate. Fertile plants] . . I. pallida s.1.

$2 \mathrm{~b}$ Bracts and bracteoles partially scarious or herbaceous at anthesis. Limb of the fall has dark veins on a brighter background in the basal part of the upper surface. Limb of the standard moderately to finely undulate. $2 \mathrm{n}=(24) 44,48 \ldots \ldots \ldots \ldots \ldots$

3a Flowers generally bright pinkish- to lavender-violet (similarly to $I$. aphylla), concolorous. Limb of the fall obovate; brighter basal background occupies no more than 20(25)\% of the upper surface. Bracts and bracteoles herbaceous to slightly scarious at anthesis, inflated. $2 \mathrm{n}=48$ [Fertile plants]. . . . . . . . . . . . . . I. croatica

3a Flowers generally less-saturated violet (more nuances), but rarely completely bright pinkish- to lavender-violet, concolorous or bicolorous. Limb of the fall obovate to obovate-spathulate; brighter basal background occupies (20)25-40(50)\% of the upper surface. Bracts and bracteoles partially scarious at anthesis, rarely herbaceous and inflated. $2 \mathrm{n}=(24) 44,48$

4a Unfertile to slightly fertile plants, up to $70(80) \mathrm{cm}$ height. Flowers usually concolorous. Brighter basal background of the fall limb occupies (20)25-30\% of the upper surface; whitish, rarely suffused with pale yellow. $2 \mathrm{n}=44$ 
$4 \mathrm{~b}$ Unfertile to fertile plants, up to $100(120) \mathrm{cm}$ height. Flowers usually bicolorous, with brighter standards. Brighter basal background of the fall limb occupies (25)30-40(50)\% of the upper surface; usually suffused with pale yellow. $2 \mathrm{n}=24,48 \ldots \ldots$. . . . ×trojana aggr.

Iris pallida is included as parental species in all of the mentioned groups. Different taxonomic treatments of its entities led to a more intricate understanding of descendant $I$. × germanica complex s.l. Three species have been separated from I. pallida: I. cengialti Ambrosi ex A. Kern., I. illyrica Tomm. ex Vis. and I. pseudopallida Trinajstić. Some of them are currently recognised at the rank of subspecies (Barker \& Govaerts 2018), although Colasante \& Maury (2018) presumed that they might be doubtful.

\section{MATERIAL AND METHODS}

The collected plant material is stored in the Herbarium of the Natural History Museum in Belgrade (BEO) and the Herbarium of the Institute of Botany and Botanical Garden "Jevremovac", University of Belgrade (BEOU). Reproductive abilities of hybrid and parental individuals were monitored in the habitat over a period of ten years. They are vegetatively propagated and also monitored in ex situ culture.

Horticultural classification follows Warburton \& Gantz (1970). Characters with no alternatives in identification keys are given in italics in square brackets.

The total nuclear DNA amount was assessed by flow cytometry according to Bourge et al. (2018) using fresh leaves of samples and internal standards, Triticum aestivum L. "Chinese Spring" $(2 \mathrm{C}=30.9 \mathrm{pg})$ (Marie \& Brown 1993).

Small parts of leaves (approx. $0.5 \mathrm{~cm}^{2}$ ) of both internal standard and target species were simultaneously chopped using a razor blade in a plastic Petri dish with $600 \mu 1$ of Gif nuclei-isolation buffer (Bourge et al. 2018): [45 mM MgCl2, $30 \mathrm{mM}$ sodium citrate, $60 \mathrm{mM}$ MOPS (4-morpholine propane sulphonate, $\mathrm{pH} 7)$, and $1 \%(\mathrm{w} / \mathrm{v})$ polyvinylpyrrolidone $10,000, \mathrm{pH}$ 7.2] containing $0.1 \%(\mathrm{w} / \mathrm{v})$ Triton $\mathrm{X}-100$ and supplemented with $5 \mathrm{mM}$ sodium metabisulphite and RNAse $(2.5 \mathrm{U} / \mathrm{ml})$. The nuclei suspension was filtered through a $30 \mu \mathrm{m}$ nylon mesh. The nuclei were stained with 100 $\mu \mathrm{g} / \mathrm{ml}$ propidium iodide (PI), a specific DNA intercalating fluorochrome dye, and kept 5 min at $4^{\circ} \mathrm{C}$.

DNA content of about 3,000 stained nuclei was determined for each sample using a Cyflow SL3, Partec, 532-nm laser cytometer (Munster, Germany). The samples comprised from one to three individuals, measured 
separately. To check the reproducibility of values, two distinct measurements were performed for each individual.

The total nuclear DNA content was calculated based on the following formula: 2C DNA sample $(\mathrm{pg})=($ Sample $2 \mathrm{C}$ peak mean/Standard $2 \mathrm{C}$ peak mean $) \times$ Standard $2 \mathrm{C}$ DNA $(\mathrm{pg})$.

\section{RESULTS AND DISCUSSION}

Two adjacent populations of natural $I$. reichenbachii and cultivated $I$. $\times$ germanica s.l. were recorded in the southern part of C Serbia, together with two clusters of their putative hybrid. The observed mixture of phenotypic parental traits was the first evidence of the hybrid origin of the new plant. This was also supported by the investigation of DNA content, ploidy level determination and detected infertility. According to horticultural classification, it is included in Intermediate Tall Bearded Irises (IB).

Iris $\times$ seminaturalis Niketić, Tomović \& Šiljak-Yak., hybr. nov. (Figs 3-5) [=I. $\times$ germanica L. s.1. (I. ×trojana group $) \times$ I. reichenbachii Heuff.]

TYPE

C Serbia, Prokuplje, Gubetin, MGRS 34T EN488, marble, 320 m s.m., clearings in Quercetum frainetto-cerridis forest, coll. Niketić, M., Tomović, G., 30-Apr-2008, (holotype: BEO 00-64; isotype: BEOU 17470) (Fig. 6).

\section{DESCRIPTION}

Rhizome stout, horizontal, $20-50 \mathrm{~cm}$ long, branched, with uniform diameter. Stems straight, solid, $(30-) 40-45 \times 0.3-0.4(-0.8) \mathrm{cm}$, green. Leaves equitant, \pm ensiform; basal $8-25(-40) \times 1.5-2(-3.5) \mathrm{cm}$, quite smooth, green, slightly glaucescent; cauline leaves 2-3(4) in the lower part of the stem, much smaller, ensiform to slightly falcate. Inflorescences with (1)2-3 particoloured odourless flowers, lower shortly pedunculate or lowermost usually aborted; lowermost peduncles up to as long as subtending bracts. Bracts and bracteoles 3.5-4(5) cm long, slightly keeled, greenish at first and becoming white to slightly brownish, with a scarious margin (2-3 mm wide) in the upper part. Hypanthial tube 1.5-2.5 cm long. Falls 5-7.5 $\times 3-4 \mathrm{~cm}$, reflexed, with obovate limb, taper gradually to the claw; lower surface of the limb pale bluish-green; upper surface of the limb pale lilac to bluish-gray in the upper part (55-70\%), with dark violet veins, and yellowish in the lower part (30-45\%), with dark purplish veins, also with a beard of intensely orange multicellular hairs along proximal $1 / 4$ of the middle vein; beard continues on the claw. Standards erect, creamy white to pale yellowish to pale lilac, with obovate to broadly obovate limb, 5-7.5 $\times$ $3.5-4 \mathrm{~cm}$, and $0.7-1 \mathrm{~cm}$ long claw, spotted with dark purplish. Stamens 
with whitish filaments, $0.6-0.8 \mathrm{~cm}$ long, and yellowish anthers, $1-1.3 \mathrm{~cm}$ long. Ovary 1-1.5 $\times 0.5 \mathrm{~cm}$, subcylindrical. Style ca. $3 \mathrm{~cm}$ long, with pale yellowish petaloid branches, suffused with blue, dividing at apex into two short triangular and irregularly laciniate lobes. Fruits were not detected.

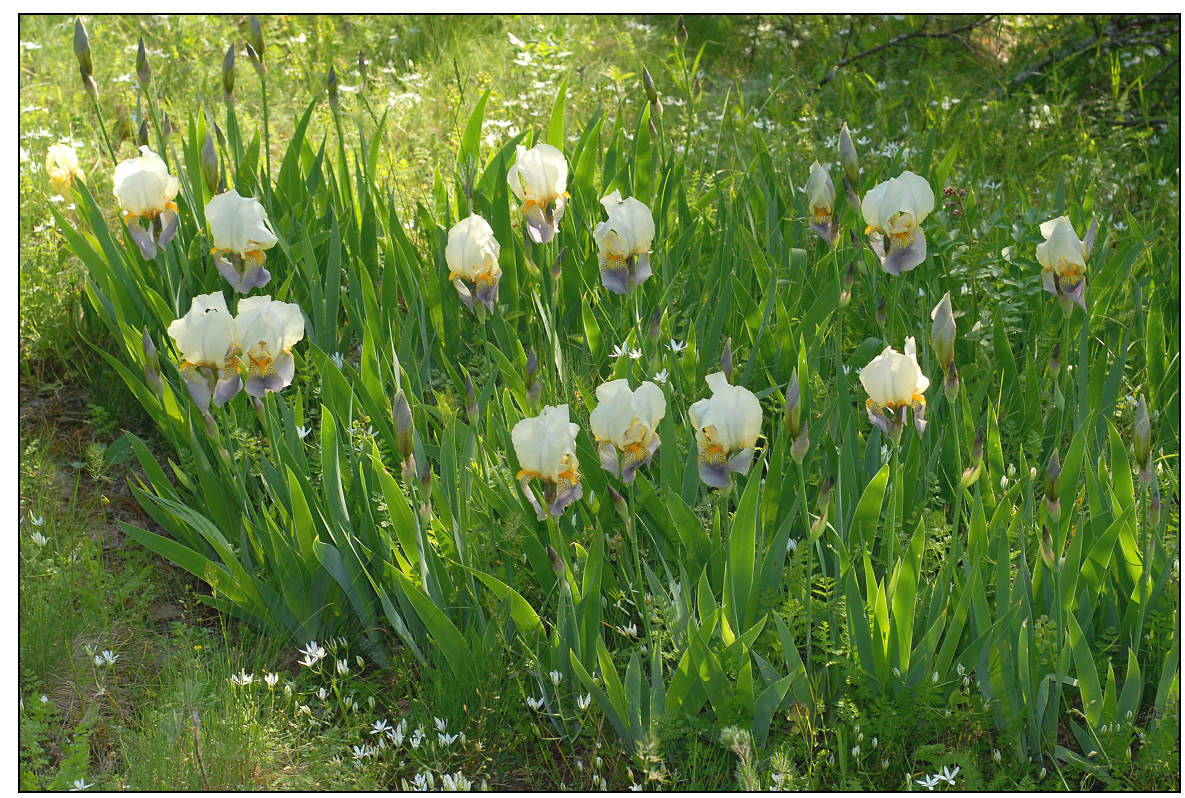

Fig. 3. - The new spontaneous hybrid Iris $\times$ seminaturalis Niketić, Tomović \& Šiljak-Yak. on natural habitat in C Serbia near Prokuplje (Gubetin) - habitus (photo M. Niketić).

\section{DIAGNOSTIC CHARACTERS}

The new iris is almost certainly an F1 hybrid between I. reichenbachii and $I$. × germanica s.l. (I. ×trojana group) and has intermediate morphology between parental taxa. It is much taller than I. reichenbachii, with larger particoloured \pm pale lilac to bluish-gray flowers (vs. yellowish) and slightly keeled, partially scarious bracts. In comparison with I. ×trojana it has lower growth, less scarious bracts and smaller and fewer flowers with pale lilac to bluish-gray falls (vs. more intense purplish-violet) which have a larger yellowish basal part on the limb.

Iris $\times$ seminaturalis also resembles several other hybrid IB irises (cultivated or natural). It is very similar to the bicolorous cultivar $I$. × conglomerata 'Progenitor', registered in 1951 (Sekerka et al. 2013), which also emerged in $\mathrm{F} 1$ generation by way of crossing I. reichenbachii with another cultivar, I. × conglomerata 'Shining Waters'. Our hybrid differs by pale lilac to bluish-gray falls (vs. more intense purplish-violet) with distinctly larger yellowish basal part on the limb, also by \pm uniformly coloured standard limb (without purplish-violet midvein). 


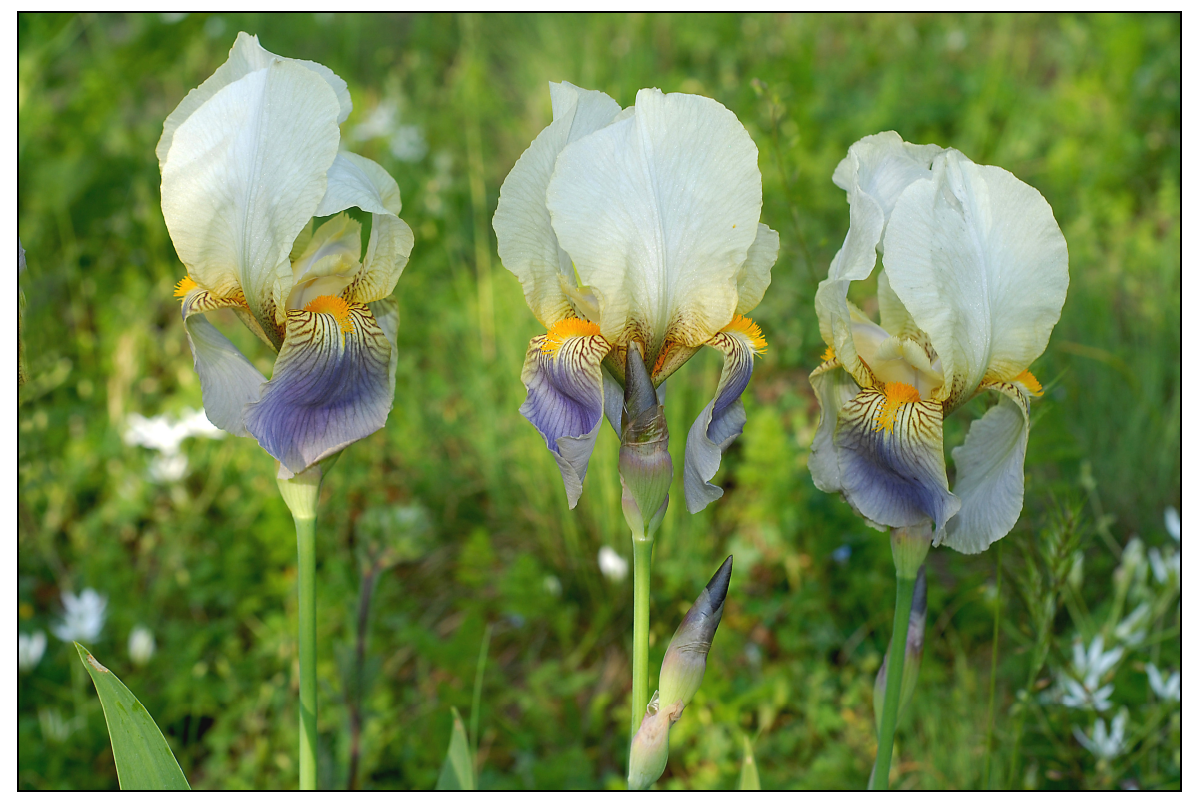

Fig. 4. - The new spontaneous hybrid Iris $\times$ seminaturalis Niketić, Tomović \& Šiljak-Yak. on natural habitat in C Serbia near Prokuplje (Gubetin) - flowers (photo M. Niketić).

Recently described I. orjenii (Bräuchler \& Cikovac 2007) has I. pseudopallida (from I. pallida group) and I. reichenbachii as putative parent species. Iris $\times$ seminaturalis is recognisably different from $I$. orjenii and has narrower leaves, less scarious bracts, particoloured \pm pale lilac to bluish-gray flowers (vs. concolorous, white to very pale yellow) and obovate limb of the fall (vs. obovate to spathulate).

In relation to $I$. rotschildii (I. pallida $\times I$. variegata) it has obovate pale lilac to bluish-gray limb of the fall (vs. obovate-spathulate and purplishviolet) with darker veins only in the basal part of the upper surface (vs. on the entire upper surface, similar to I. variegata).

\section{DNA CONTENT AND CHROMOSOME NUMBER}

Total nuclear DNA assessed by flow cytometry confirmed the hybrid origin of individuals. They are described as hybrids according to their morphology, which is intermediary between $I$. $\times$ germanica s.1. and $I$. reichenbachii. The parents are diploid (I. reichenbachii, $2 \mathrm{n}=24,2 \mathrm{C}=$ $12.76 \mathrm{pg}$ ) and tetraploid (I. × germanica s.1., $2 \mathrm{n}=48,2 \mathrm{C}=24.96 \mathrm{pg}$ ) while the hybrid has genome size of $2 \mathrm{C}=19.38 \mathrm{pg}$ corresponding to triploid plant $(2 \mathrm{n}=36)$. 


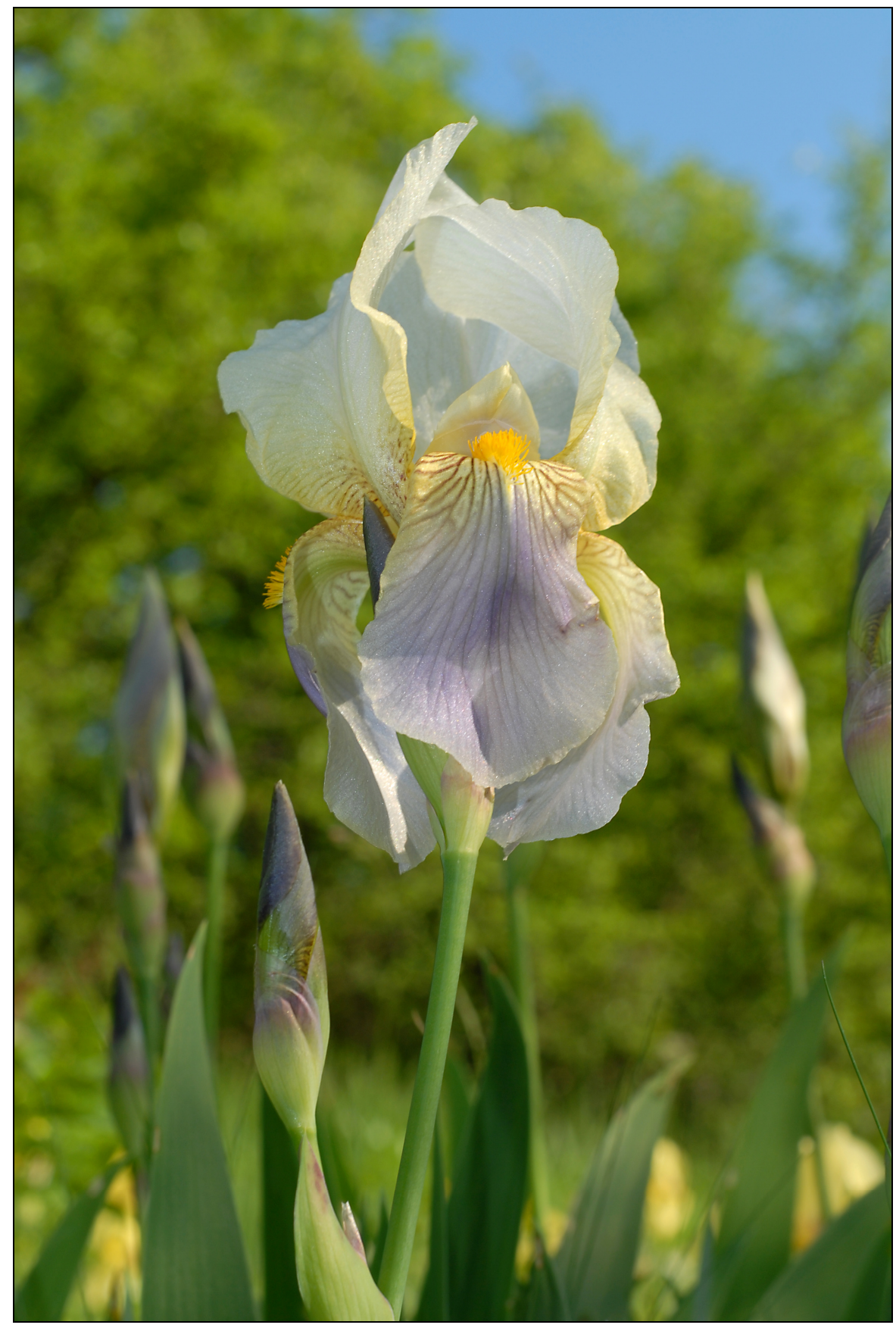

Fig. 5. - The new spontaneous hybrid Iris $\times$ seminaturalis Niketić, Tomović \& Šiljak-Yak. on natural habitat in C Serbia near Prokuplje (Gubetin) - flower (photo M. Niketić). 
NIKETIĆ, M. ET AL.: A NEW SPONTANEOUS IRIS HYBRID FROM SERBIA

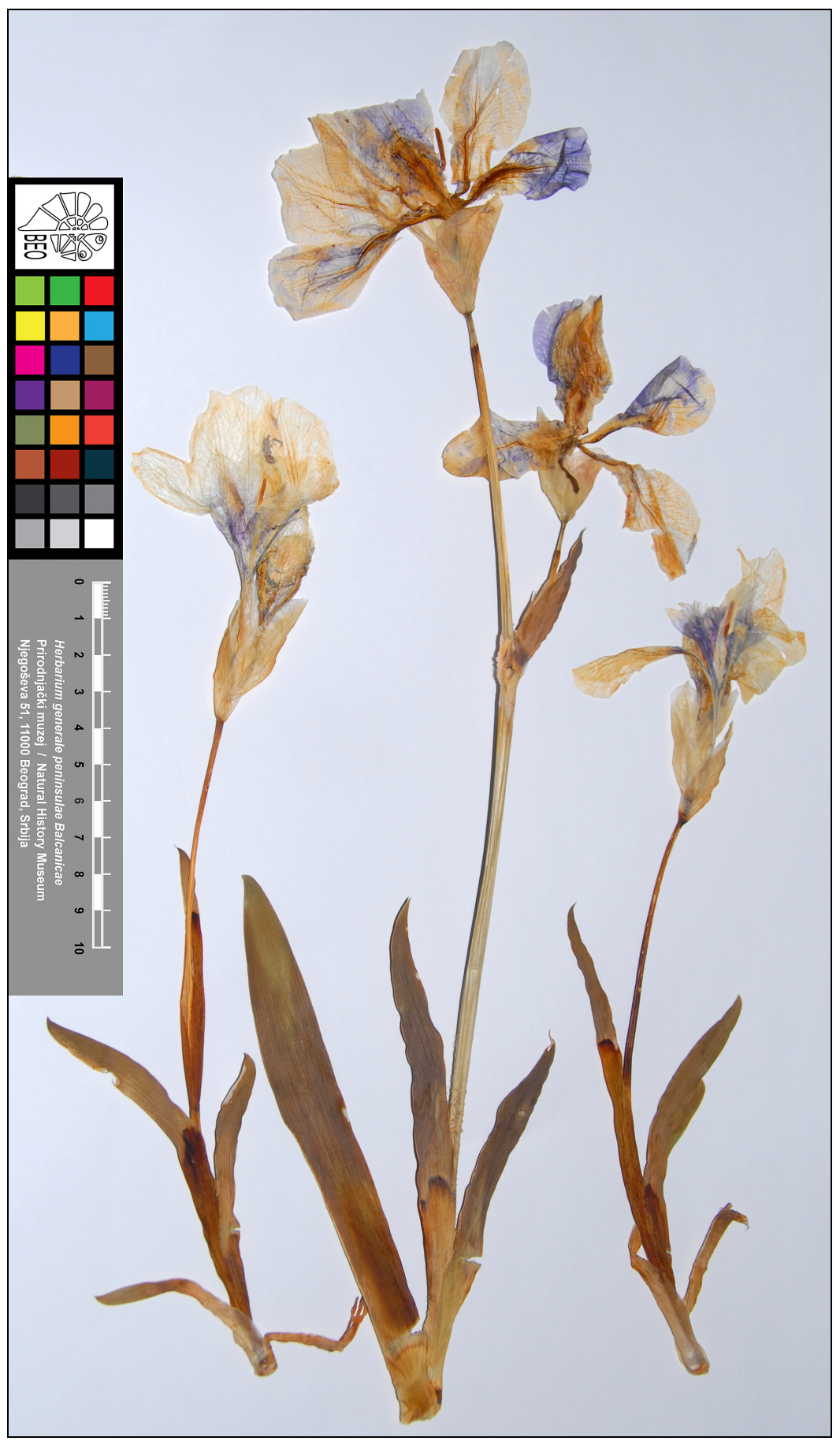

Fig. 6. - Iris ×seminaturalis Niketić, Tomović \& Šiljak-Yak. holotype (BEO 00-64). 


\section{REPRODUCTION}

Despite the population monitoring since 2008, fertile individuals have not been found at the investigated locality to date, either in the newly described hybrid or the progenitors. Accordingly, it can be concluded that $I$. $\times_{\text {seminaturalis }}$ is probably a sterile triploid of F1 generation. Therefore, introgression with the parental taxa probably does not occur. The lack of fruits in fertile $I$. reichenbachii could be explained by population decreasing in conditions of permanent reforestation and shading of habitat, since there are currently only a few individuals remain. Fruits are also not seen in parental hybrid $I$. × germanica s.l., but the production of pollen grains has been noted. Consequently, it can be assumed that $I$. $\times$ germanica s.1. is probably the male parent, while $I$. reichenbachii is the female. The new hybrid has been successfully propagated vegetatively in garden conditions.

DISTRIBUTION AND ABUNDANCE

So far, I. × seminaturalis is known only from one locality in the surroundings of Prokuplje in C Serbia. Only two adjacent clusters were found within the population of I. reichenbachii.

\section{ADDITIONAL SPECIMENS EXAMINED}

C Serbia, Prokuplje, Gubetin, MGRS 34T EN488, marble, 320 m s.m., clearings in Quercetum frainetto-cerridis forest, coll. Niketić, M., Tomović, G., 01-May-2002 (BEO 82881; 15442 BEOU).

\section{HABITAT AND ECOLOGY}

The new hybrid inhabits the thermophilous variant of Balkan climatogenic deciduous forests of Hungarian and Turkey oak, Quercetum frainetto-cerridis Rudski (1940) 1949 subass. pubescentosum Jovan. The plant grows in the lowland-colline belt (320 m s.m.) on brown soil and on carbonate bedrock (marble). It appears in small patches of forest clearing, together with its parental species, I. reichenbachii (Fig. 7). In conditions of permanent reforestation, the plant grows in more sunny forest environments with remains of steppic fescue pastures, Sanguisorbo-Festucetum valesiacae Danon 1960 subass. koelerietosum macranthae Diklić 1962. The herbaceous-subshrub layer of the forest includes: Cytisus hirsutus L., Genista tinctoria subsp. ovata (Waldst. \& Kit.) Arcang., Festuca valesiaca Schleich. ex Gaudin, Sanguisorba minor Scop., Koeleria macrantha (Ledeb.) Schult., Ornithogalum kochii Parl., Fragaria vesca L., Poa bulbosa L., Medicago rigidula (L.) All., Veronica prostrata L., Veronica jacquinii Baumg., Lathyrus sphaericus Retz., Ajuga chamaepitys (L.) Schreb., Dictamnus albus L., Ranunculus psilostachys Griseb., Anchusa officinalis L., Euphorbia epithymoides L., Onobrychis alba (Waldst. \& Kit.) Desv., Verbascum banaticum Schrad., Melampyrum arvense L., Cerastium brachypetalum Desp. ex Pers., Potentilla recta L. subsp. pilosa (Willd.) Rchb. f. ex Rothm., Potentilla astracanica subsp. pirotensis (Borbás) Soják, 
Teucrium chamaedrys L., Geranium columbinum L., Draba muralis L., Orlaya grandiflora (L.) Hoffm., Muscari neglectum Guss. ex Ten., Lamium purpureum L., Stellaria media (L.) Vill., Scorzonera hispanica L., Neotinea tridentata (Scop.) R. M. Bateman, Orchis purpurea Huds., Pridgeon \& M. W. Chase, Helianthemum salicifolium (L.) Mill., etc.

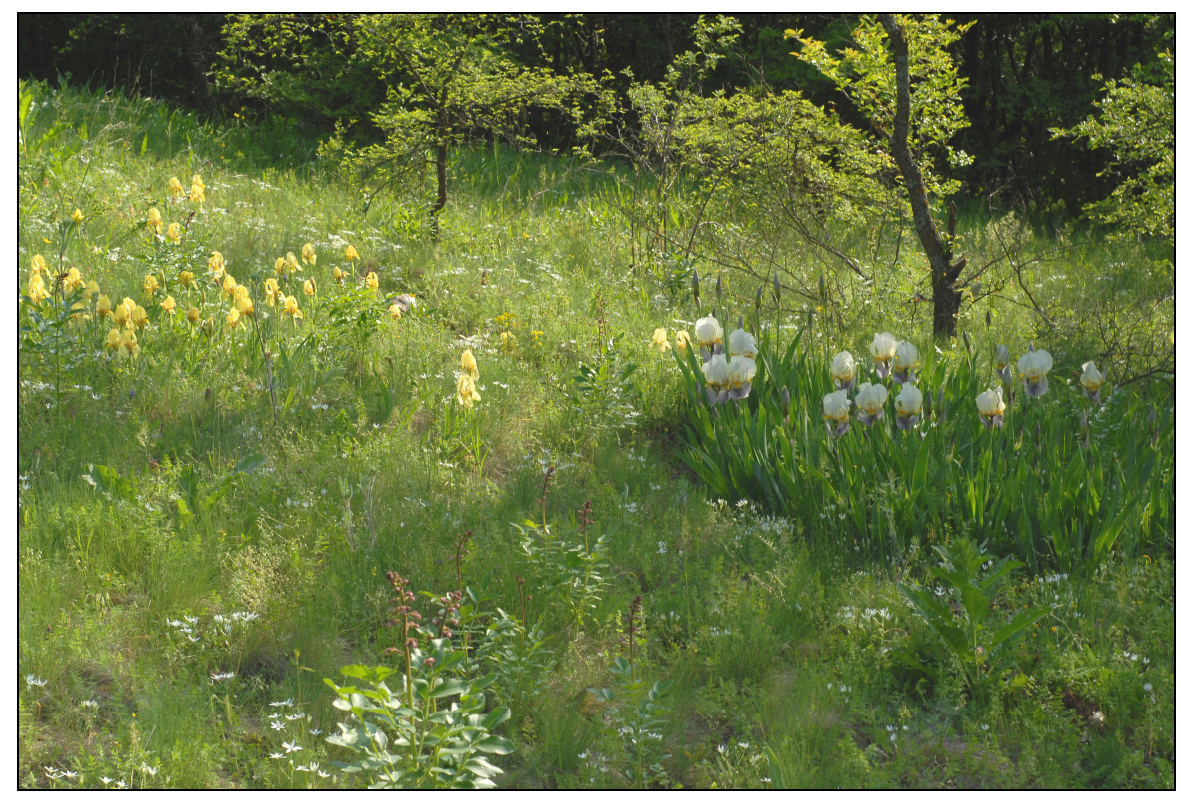

Fig. 7. - Parental species Iris reichenbachii Heuff. (on the left) and the new hybrid I. $\times$ seminaturalis Niketić, Tomović \& Šiljak-Yak. (on the right) on natural habitat in C Serbia near Prokuplje (photo M. Niketić).

\section{ORIGIN AND TAXONOMIC POSITION}

In addition to $I$. reichenbachii, another parental plant belongs to $I$. $\times$ germanica complex. Judging by the number of chromosomes $(2 n=48)$, it may be considered to be a member of $I$. $\times$ trojanensis group, but due to unresolved taxonomy, definitive identification has not been performed. This group includes some old clones that are traditionally cultivated in rural areas of Serbia and the Balkans. Observed plants, cultivated in a nearby village cemetery, have recently become pollen donors in crossing with wild individuals of I. reichenbachii. This type of spontaneous crossing between the decorative plants and indigenous species in their habitat is very rare - e.g., in Larix Mill. (Meirmans et al. 2014). So far, crossings between autochthonous and agricultural plants (or trees from plantations) have been recorded much more often (Dostálek 1984, Ammitzbøll \& Jørgensen 2006, Zaharieva \& Monneveux 2006, Schierenbeck \& Ellstrand 2009, Paffetti et al. 2018).

Iris $\times$ seminaturalis is most similar to the hybrid iris cultivar, $I$. $\times$ conglomerata 'Progenitor'. However, in addition to I. reichenbachii, 
some other species (I. pallida, I. variegata, I. kashmiriana) as well as 18 hybrids has been involved in artificial crossing, including four tetraploids from $I$. $\times$ trojanensis group.

Hybridogenous $I$. orjenii (I. pseudopallida $\times I$. reichenbachii) is somewhat related to $I$. $\times$ seminaturalis, but this diploid plant $(2 \mathrm{n}=24)$ may have arisen as a result of homoploid hybrid speciation.

Another potentially related taxon could be $I$. $\times$ kobasensis. According to Barker \& Govaerts (2018) it is a natural hybrid between I. reichenbachii and $I$. variegata. However, it was erroneously described as an intermedial species between I. lutescens ["I. virescens"] and I. reichenbachii ["I. bosniaca"] from Bosnia and Herzegovina (Mt Vitorog) (Prodan 1935). Furthermore, according to the original description, the plant is not so different from I. reichenbachii, and no similarities with I. variegata were indicated. Consequently, the hybrid origin of this plant (actually most probably I. reichenbachii) has to be rejected.

\section{Acknowledgements}

The Ministry of Education, Science and Technological Development of the Republic of Serbia supported this research through Grant 173030 "Plant biodiversity of Serbia and the Balkans - Assessment, Sustainable Use and Protection". Aco Teofilovski has provided us with important informations about Iris $\times$ germanica s.l. in Macedonia.

\section{REFERENCES}

Abdel Samad, N., Bou Dagher-Kharrat, M., Hidalgo, O., El Zein, R., Douaihy, B., Siljak-Yakovlev, S. (2016): Unlocking the Karyological and Cytogenetic Diversity of Iris from Lebanon: Oncocyclus Section Shows a Distinctive Profile and Relative Stasis during Its Continental Radiation. - PLoS ONE 11(8): e0160816.

Aldén, B. (1976): Floristic reports from the high mountains of Pindhos, Greece. Botaniska Notiser 129(3): 297-321.

Ammitzbøll, H., Jørgensen, R. B. (2006): Hybridization between oilseed rape (Brassica napus) and different populations and species of Raphanus. Environmental Biosafety Research 5: 3-13.

Anonymous (1923): Description of Varieties, Part 2. - Bulletin of The American Iris Society 7: $20-34$.

Barker, C., Govaerts, R. (2018): Iridaceae. In: World Checklist of Arecaceae. Royal Botanic Gardens, Kew. [http://wcsp.science.kew.org/]

Blažek, M. (2016): 'Amas' and 'Macrantha' Known and Unknown Irises. - Roots Journal of the Historic Iris Preservation Society 29(1): 10-14. 
Bourge, M., Brown, S. C., Siljak-Yakovlev, S. (2018): Flow cytometry as tool in plant sciences, with emphasis on genome size and ploidy level assessment. Genetics \& Application 2(2): 1-12.

Bräuchler, C., Cikovac, P. (2007): Iris orjenii (Iridaceae) - a new species from the littoral Dinaric Alps. - Willdenowia 37(1): 221-228.

Colasante, M. A., Maury, A. E. (2018): Iridaceae Present in Italy. - Sapienza Univerzità Editrice, Roma.

Degen, A. (1936): Flora Velebitica 1. - Die Ungarische Akademie der Wissenschaften, Budapest.

Dostálek, J. (1984): Hybriden von Pyrus spinosa. - Folia geobotanica et phytotaxonomica 19: 89-93.

Dykes, W. R. (1913): The Origin of some Garden Irises. - The Gardeners' Chronicle, ser. 3, 53: 321-322.

Dykes, W. R. (1914): Some Garden Irises. - Journal of the Royal Horticultural Society of London 40: 226-233.

Dykes, W. R. (1914a): The Origin of some Garden Irises. - The Gardeners' Chronicle, ser. 3, 56: 48-49.

Dykes, W. R. (1924): A Handbook of Garden Irises. - Martin Hopkinson, London.

Gessert, G. (2010): Green Light. Towards an Art of Evolution. - The Mit Press, Cambridge, Massachusetts, London, England.

Henderson, N. C. (1992): What is Iris germanica? - Bulletin of the American Iris Society 286: 6-11.

Henderson, N. C. (1993): Iris ×conglomerata. - Bulletin of the American Iris Society 290: 17-22.

Henderson, N. C. (2002): Iris Linnaeus. In: Editorial Committee (eds.): Flora of North America North of Mexico 26. Magnoliophyta: Liliidae: Liliales and Orchidales: 371-376. - Oxford University Press, New York, Oxford.

Horvat, I., Horvat. M. (1962): Iris croatica - A New Species of Iris from Croatia - Acta Botanica Croatica 20-21: 8.

Jarvis, C. E., Barrie, F. R., Allan, D. M., Reveal, J. L. (1993): A List of Linnean Generic Names and their Types. - Regnum vegetabile 127: 5-100.

Mahan, C. E. (2007): Classic Irises and the Men and Women Who Created Them. - Krieger Publishing Company, Malabar, FL.

Mathew, B. (1981): The iris. - Universe Books, New York.

Mathew, B. (1984): Iris L. In: Davis, P. H. (ed.): Flora of Turkey and the East Aegean Islands 8: 382-410.

Mathew, B. (1991): Iris L. In: Strid, A. (ed.): Mountain Flora of Greece 2: 719-722.

Meirmans, P. G., Gros-Louis, M-C., Lamothe, M., Perron, M., Bousquet, J., Isabel, N. (2014): Rates of spontaneous hybridization and hybrid recruitment in coexisting exotic and native mature larch populations. - Tree Genetics \& Genomes 10 p.: 965-975.

Mermygkas, D., Tan, K., Yannitsaros, A. (2010): A new species of Iris (Iridaceae) from the northern Peloponnese (Greece). - Phytologia Balcanica 16(2): 263 - 266. 
Mitra, J. (1956): Karyotype Analysis of Bearded Iris. - Botanical Gazette 117(4): 265-293.

Mitić, B., Halbritter, H., Šoštarić, R. Nikolić, T. (2013): Pollen morphology of the genus Iris L. (Iridaceae) from Croatia and surrounding area: taxonomic and phylogenetic implications. - Plant Systematics and Evolution 299: 271-288.

Marie, D, Brown, S. C. (1993): A cytometric exercise in plant DNA histograms with $2 \mathrm{C}$ values for 70 species. - Biology of the Cell 78: 41-51.

Murray, E. (1969): Iris $\times$ altobarbata, a new species. - Kalmia 1: 25.

Paffetti, D., Travaglini, D., Labriola, M., Buonamici, A., Bottalico, F., Materassi, A., Fasano, G., Nocentini, S., Vettori, C. (2018): Land use and wind direction drive hybridization between cultivated poplar and native species in a Mediterranean floodplain environment. - Science of the Total Environment 610-611: 1400-1412.

Popova M. T., Česchmedjiev, I. (1975): IOPB Chromosome number Reports XLVII. In: Löve, A.: IOPB Chromosome number Reports. - Taxon 24(1): 143-146.

Preston, C. D., Pearman, D. A. (2015): Plant hybrids in the wild: evidence from biological recording. - Biological Journal of the Linnaean Society 115: 555-572.

Prodan, J. (1931): Die Flora der Dobrudscha und ein kurzer überblick über die Flora der Meeresküste Rumäniens. - Buletinul Ministerul Agriculturii și Domeniilor, ser. 3, 2: 3-95.

Prodan, J. (1935): Die Iris-arten Rumäniens. - Buletinul Grădinii Botanice şi al Muzeului Botanic dela Universitatea din Cluj 14(3-4): 105-198.

Prodan, J. (1939): Critical consideration of one species of the genus Iris. - Bulletin of the Agricultural Academy of Cluj 8(2): 1-13. [in German]

Randolph, L., Mitra, J. (1959): Chromosome numbers of Iris species. In: Randolph, L. (ed.): Garden Irises: 537-542. - American Iris Society, St. Louis.

Schierenbeck, K. A., Ellstrand, N. C. (2009): Hybridization and the evolution of invasiveness in plants and other organisms. - Biological Invasions 11: 10931105.

Sekerka, P., Blažek, M., Blažková, U., Caspers, Z., Macháčková, M., Žlebčík, J., Polesný, V. (2013): Průvodce po sbírkách Průhonické botanické zahrady na Chotobuzi. - Botanický ústav AV ČR, v. v. i., Průhonice [in Czech]

Siljak-Yakovlev, S, Bogunić, F., Muratović, E., Šolić, M. E., Pavlović, D. \& Medjedović, S. (2005): Genome organization of some Iris species assessed by molecular cytogenetics. - In: XVII International Botanical Congress, Vienna, Austria, 17 - 23 July: 384.

Siljak-Yakovlev, S., Robin, O., Biljaković, M., Till-Bottraud, I. (2008): Molecular cytogenetic confirmation of hybrids between Iris variegata and Iris illyrica in Dinaric Alps. - In: Abstracts of The Fourth International Conference on the Comparative Biology of the Monocotyledons \& The Fifth International Symposium on Grass Systematics and Evolution, August 11 - August 15, 2008 University of Copenhagen Denmark.

SFIB (2018): Iris germanica L. - French Society of Irises and Bulbous Plants (SFIB) [http://www.iris-bulbeuses.org/iridaceae/iris-germanica.htm] 
Simonet, M. (1952): Noveaux dénombrements chromosomiques chez les Iris. Compte Rendu de l'Académie des Sciences, Paris. Serie 3, Sciences de la Vie 235(21): 1244-1246.

Stjepanović-Veseličić, A. (1976): Fam. Iridaceae. - In: Josifović, M. (ed.): Flora

SR Srbije 8: 1-31. - Srpska akademija nauka i umetnosti, Beograd.

Warburton, B. A., Gantz, C. O. (eds.) (1970): The Eupogon Iris Species in Cultivation. - MIS Press-Hudson Printers, Westborough, Massachusetts.

Webb, D. A., Chater, A. O. (1980): Iris L. In: Tutin, T. G., Heywood, V. H., Burges, N. A., Moore, D. M., Valentine, D. H., Walters, S. M., Webb, D. A. (eds): Flora Europae 5: 87-92. - Cambridge University Press, Cambridge.

Werckmeister, P. (1981): - Iriszuchtung. In: Köhlein, F. Iris. - Eugen Ulmer GmbH \& Co., Stuttgart.

Williams, C. A., Harborne, J. B., Colasante, M. (2000): The pathway of chemical evolution in bearded Iris species based on flavonoid and xanthone patterns. Annali di Botanica 58: 51-58.

Wister, J. C. (1978): The History of Iris Development. In: The World of Irises. American Iris Society, Wichita, Kans.

Yu, X-F., Zhang, H-Q., Yan, M., Zhou, Y-H. (2007): Karyotype studies on ten Iris species (Iridaceae) from Sichuan, China. - Caryologia 62(3): 253-260.

Zaharieva, M., Monneveux, P. (2006): Spontaneous Hybridization between Bread Wheat (Triticum aestivum L.) and Its Wild Relatives in Europe. - Crop Science 46: 512-527.

\title{
НОВИ СПОНТАНИ ХИБРИД ИЗМЕЪУ КУЛТИВИСАНЕ И ДИВЉЕ ВРСТЕ ПЕРУНИКЕ ИЗ СРБИЈЕ
}

\author{
MAРЈAН НИКЕТИЋ, ГОРДАНА ТОМОВИЋ, SONJA SILJAK-YAKOVLEV
}

\section{Р Е 3 И М Е}

Нови спонтани самоникли хибрид, Iris $\times$ seminaturalis Niketić, Tomović \& Šiljak-Yak. (I. × germanica L. s.l. × I. reichenbachii Heuff.) из централне Србије, описан је и илустрован у овом раду. Компаративна анализа морфолошких карактера, величине генома и дедукција броја хромозома обављени су на узорцима $I$. × seminaturalis и њених прогенитора. Такође је дат нови таксономски осврт на комплекс $I$. ×germanica s.l. 